\title{
THE ANALYSIS OF VIOLATION OF MAXIMS IN CONVERSATIONAL IMPLICATURE FOUND IN DJARUM 76 ADVERTISEMENTS JIN VERSION
}

\author{
I Luh Meiyana Ariss Susanti ${ }^{1}$, Gede Hendri Setiawan ${ }^{2}$ \\ ${ }^{1} J u r u s a n$ Pendidikan Bahasa Inggris, STKIP Agama Hindu Singaraja, Bali. \\ 2Jurusan Pendidikan Olahraga, STKIP Agama Hindu Singaraja, Bali. \\ e-mail: meysusanti14@yahoo.com , hendriklempeh@gmail.com
}

\begin{abstract}
This study aimed to analyze the violation of maxims in conversational implicature found in djarum 76 advertisements "Jin Version" and find out the audiences understanding about the Djarum 76 Advertisements "Jin Version" with a violation of Grice maxims in their conversation, this study used qualitative descriptive method to find out the violation of Gricean maxims. And to know the effect of maxims violation in delivering the advertisements messages, the researcher spread the questionnaire to the society by taking 30 peoples as sample. From the result of violation analysis, there were four types of Grice maxims violated. And then from the result of questionnaire analysis, the researcher found out that the advertisement was attractive. Based on those data the researcher concluded that the audiences interest to watch the advertisements and they understand enough with the messages which was deliver by Djarum 76 "Jin Version" although there were Gricean maxims violations.
\end{abstract}

Keywords : Gricean Maxim, Implicature, Violation, Iklan Djarum 76 Jin Version.

\section{Pendahuluan}

In communication process, we should give the same contribution to others, so that the two-way of communication can run smoothly. It is also happened in advertising. Advertising is became one of the tools of communication which was used to offer the products or services to the public, so that the information submission should use language that was easily to be understood by the consumer and more using persuasive language in other to make the consumer interest and would buy the product. But, $\mathrm{n}$ more cases, many advertiser violated the communication requirement and used a language that contained of implicature. The requirement in the question is called cooperative principles. Grice (1975) stated that, there is a general cooperative principle between speaker and hearer which control and guide the way they speak. In other word this principles can be determined as a norm that required the speakers to contribute meaningful to the conversation to what is needed. These principles are described in to four categories of maxims. There are :1) Maxim of quantity that require the speaker to make their contribution as informative as is required and do not make our contribution more informative than is required, 2) maxim of quality that required the speakers to do not say what we believe to be false and do not said that for which we luck evidence, 3) Maxim of relevance that required the speakers to be relevant or not making a response or observation which is very obviously irrelevant to the topic in hand, 4) Maxim of manner that required the speakers to avoid obscurity of expression, avoid ambiguity, be brief and be orderly. Those maxims are really important to recognize, so that the audience would be able to interpret and catch the purpose of the advertisements and the advertisement did not contain of conversational implicature. Grice (in Yule 1996:69) says, conversational Implicature is used to describe what may be interpreted, suggested, or intended by the speaker, which is different from what was actually said by speakers in conversation. So that it is become something that is very important to note so that the conversation can take place smoothly. 
The used of conversational implicature frequently appeared in advertising. One of manufacture which was using $\mathrm{Cl}$ in their advertising is Djarum 76 cigarette manufacture. Different with the other cigarette manufacture which was always showed macho man and adventure as the icon of their product, Djarum 76 advertisements introduce their advertisement namely Djarum 76 advertisement "Jin version" where the Genie figures which is acted by Totos Rasiti become the icon of this advertisements. Beside that this advertisement also contained of critical social which was hidden in every utterance in Djarum 76 advertisement, sothat it would be nice if the advertisements used simple language than conversational implicature, so that the message of the advertisement would be easier to be understood by the audience and make them respect to the product and their country.

The audience's perception was really important to note, so that the manufacture will be easier to recognize their product existence. As what the writer said before, the understanding of the message which was delivered through advertising will be parameter of the consumer interest to by the product, remembering that advertising is aimed to influence the audiences or consumer to buy the product, so that the quality and the easier understanding about the product were really important to note.

From the exposure above, This study was expected to find what kinds of maxim were violated in that conversation. This was also aim to clarify the message or the purpose of the utterance, so that the purpose of the speech could be interpreted correctly by the audience and in accordance with cooperative principle. Besides that, the researcher also interested to analysis the audience perception about Djarum 76 advertisements "Jin Versions". This is expected to know the audience perception about Djarum 76 advertisement "Jin Version" whether the audience understood and interested to watch Djarum 76 advertisement "Jin Version"or not because there are violation of Grice maxims.

\section{Metode}

The study concerned with the conversational implicature that occured in the dialogue of Djarum 76 advertisements "Jin Version". It was aimed to investigate what kinds of maxims are violated in conversational implicature that found in dialogue Djarum 76 advertisements "Jin Version". This research used the theory of cooperative principles which was proposed by Grice (1975) to identify the forming process of conversational implicature and deternine the type of of maxims was violated.

The study used qualitative study and content analysis as the research design. One can undertake qualitative in a natural phenomena where the writer works as the primary instrument of data collection that compiles words, analyzes then inductively, concerns with the meaning of participants, and describes an expressive language processes (Creswell, 1998). In this case, the writer collected the whole data related to utterances in dialogue Djarum 76 advertisements "Jin Version" The research design was content analysis dealt with someone's utterances. According to Ary et al (2002) content analysis deals with analyzing and interpreting recorded material within its own context such as public records and textbooks

The subject of this research was the Story board of Djarum 76 Advertisement "Jin Version" while the objects of these studies were included all conversation in Djarum 76 advertisement "Jin Version". The selection of this subject was based on the utterances that violated the maxim of quantity, maxim of quality, maxim of relevant, and maxim of manner.

The research procedure conducted in two stages there were analysis Grice cooperative principles of the conversation that appear in Djarum 76 "Jin Version" and analysis audience perception about Djarum 76 advertisement "Jin Version". For the first stage, the researchers began from downloading the video of Djarum 76 advertisement "Jin Version". Then researcher collect the conversation which was taken from Djarum 76 advertisement "Jin Version" as data documentation and gathering the data transcription in to written form, after that the researcher analyzed the data by grouping them in to 4 maxim 
categories, there are: maxim of quantity, maxim of quality, maxim of relevant, maxim of manner and after that the researcher analyzed them by using Grice theory of cooperative principles, and the last step was drawing the conclusion.

The second stages, the researcher began from making the questionnaires, then choosing sample. Sample is a small part of population who were subjected to experiments (Subroto, 1992: 32). Sample in this research is conducted with a purposive sampling, in this case the informant was taken and deemed elected to represent the public's perception about Djarum 76 advertisements "Jin Version" After that, the researcher collected the questionnaires that had been filled by the respondent as documentations, and then the researcher analyzed the result of questionnaires. Before making the conclusion, the researcher also did data triangulation to check the data validity and the last step was drawing the conclusion. Total samples taken were 30 peoples which was consisting of 10 teenager (12-17 years old), 10 adult women (21-35), and 10 adult guy (21-35).

The researcher used content analysis of documentation to collect the data about the conversation which is done by the actor in Djarum 76 advertisement "Jin Version" seen from Gricean maxims. in this case the used of recorder as research instrument for downloading Djarum 76 advertisements "Jin Versions" was really helpful. Besides that, the researcher took the documentation from survey's result where the documentation was coming from the survey that conducted by the researcher by using questionnaire. The researcher used psychographic sections in making questionnaires where the section focused on the research questions. The questionnaire was drafted in simple sentences consisting of 15 questions.

In method of data analysis, the researcher used scheme modification of research procedures by Miles and Humberman (1994), where the stages was separated into two section in other to make the analysis more focus on the data which had been collected, so that it could be easier to answer the research question. The method of data analysis conducted in four categories, there are:

a. Data collection.

To answer the first question the research conducted from recording all the data which was referred to the study. In this case, the data collection was done by recording all vidios of Djarum 76 advertisements "Jin version" that aired on television, watching the vidios of djarum 76 advertisements to check the accurateness of the transcription with the motion picture, gathered the data transcription which was taken from videos of Djarum 76 advertisements "Jin Version" in to written form as the last step in data collection.

To answer the second question the research conducted from making the questionnaire, spread out the questionnaires to 30 person of respondent which were chosen by using purposive random sampling, giving chances to the respondents filled the questionnaires according the factual situation or their knowledge about Djarum 76 advertisements "Jin Version" without influence from researchers, fter respondent completed, respondents returned the questionnaire to the researcher.

b. Data reduction

To answer the first question the researcher sorted the utterances which violated the conversational maxim, enlisting these utterances based on the type conversational maxim that being violated there were: maxim of quantity, maxim of quality, maxim of relevant, maxim of manner, 3) arranging the obtainable data systematically.

To answer the second question the researcher started to collect the questionnaires that had been filled by the respondent as documentations and transcript the questionnaire's result in to a table, so that the researcher would able to make the percentages.

c. Data display

To answer the first question the researcher analyzed deeply the data which had been grouping before in to the maxim which was violated in conversation of Djarum 76 advertisements "Jin Version". In this case the researcher analyzed the violation of Grice maxim in conversational implicature. This was expected to clarify the message that wants to be delivered by the advertiser.

To answer the second question, the researcher checked the audience perception by doing deep analysis to the result of questionnaires which had been transcript in to a table, 
and then the researcher searched the percentages, so from that percentages the researcher would able to know the audience perception about Djarum 76 advertisements "Jin Version".

d. Conclusion and data verification

In this part, the researcher drowned the conclusion by doing data verification to ensure the significance or meaningfulness of the results of research so that this research data is valid.

\section{Hasil dan Pembahasan}

Djarum 76 advertisements "Jin Version" is one of PT Djarum effort to introduce and promote their cigarette product Djarum 76 to the public by taking difference concept from other cigarettes advertisement. The appearance of genie figure that acted by comedian actor who's named Totos Rasiti, bring the different concept from the other cigarette advertisements. The funny genie figure was appeared as the central character that represented the image of Djarum 76 with the aim that the audiences can quickly grasp the content of the advertising message, considering this advertisement only lasted 15-28 seconds, or in other words it was used as a reminder. but the word reminder should be note by the advertiser in making the advertisements, the chosen of the language used in advertisement should become one of intention, the used of conversational implicature must be avoided and followed the Gricean maxims so that the message can be deliver right away.

From the result of the research, where the corpus of the research consist of 10 version of Djarum 76 "Jin Version", there are, Djarum 76 advertisement "Wakil rakyat Version", Djarum 76 advertisement "Kembang Desa Version", Djarum 76 advertisement " Kontes Jin Version", Djarum 76 advertisement "Mtre Version", Djarum 76 advertisement "Pengin Sugih, Pngin Ganteng Version", Djarum 76 advertisement "Gayus Version", Djarum 76 advertisement "Jin Takut Istri Version", Djarum 76 advertisement "Korupsi, Pungli, Sogokan", Djarum 76 advertisement "Iki Salah, Iku Salah Version", and Djarum 76 advertisement "Jagkrik Version" found that the used of conversational implicature often appeared in conversation Djarum 76 advertisements "Jin Version"and tend to violate the Gricean maxims. The result of analysis violation of maxims in conversational implicature found in Djarum 76 advertisements "Jn Version" can be seen clearly below:

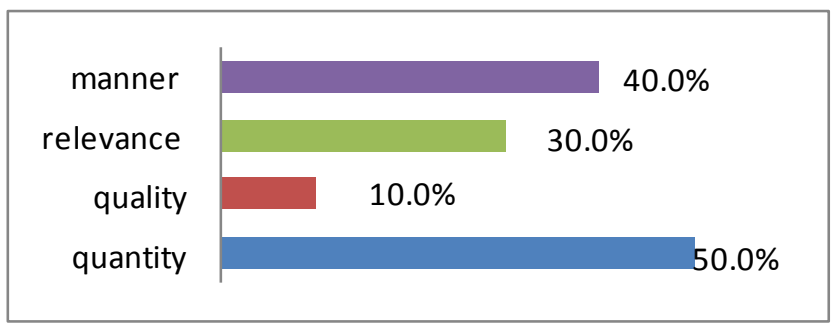

From the result of analysis found that from four types of Grice conversational maxims, there are all types of Grice maxims are violated, there are: $50 \%$ advertisements violated the maxim of quantity, $10 \%$ advertisements violated the maxim of quality, $30 \%$ advertisements violated the maxim of relevance, and $40 \%$ advertisements violated the maxim manner. This result came from deep analysis to all versions of Djarum 76 advertisements "Jin Version" as below: 


\begin{tabular}{lcccc}
\hline \multicolumn{1}{c}{ Djarum 76 Advertisements } & Quantity & Quality & Relevance & Manner \\
\hline Versi Wakil Rakyat & $\sqrt{ }$ & $\sqrt{ }$ & & $\sqrt{ }$ \\
Versi Kembang Desa & $\sqrt{ }$ & & $\sqrt{ }$ \\
$\begin{array}{l}\text { Versi Kontes Jin } \\
\text { Versi Matre }\end{array}$ & $\sqrt{ }$ & & \\
Versi Pengen Sugih, ganteng & & $\sqrt{ }$ \\
Versi Gayus & $\sqrt{ }$ & & \\
Versi Jin Takut Istri & $\sqrt{ }$ & $\sqrt{ }$ & \\
Versi Korupsi, Pungli, & & & $\sqrt{ }$ \\
Sogokan & & & \\
Versi Iki Salah Iku Salah & & & & \\
Versi Jangkrik & & & & \\
\hline
\end{tabular}

In other to know the response of the audience, the researcher made questionnaires by developing some variables which is used to deliver the message or promote Djarum 76 cigarette products, seen from the story line, figures, visual looks, message and other which was appearing in Djarum 76 advertisements "Jin Version" in to series of question that consisted of 15 question and spread the questionnaires to 30 response which was chosen by using purposive random sampling. Here are the percentages recapitulation charts of the result processing data about the audience perception to the djarum 76 advertisements "jin version".

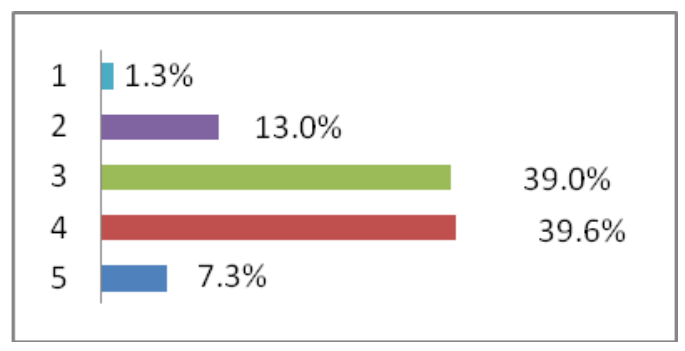

Based on that result, showed that the respondents felt in love and attracted to the Djarum 76 advertisements "Jin Version". Beside that the result showed that they understand enough with the messages of Djarum 76 "Jin Version" although there are Gricean maxims violations. Here are the detail explanations of the explanation of the respondent's answer: a. Question 1. Public knowledge about Djarum 76 advertisements "Jin Version"

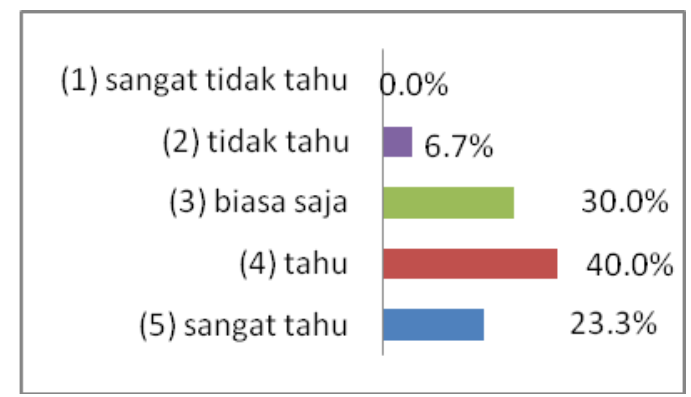

From the chart 1 , can be seen that 30 rspondents which was taken as samples, there was $23.3 \%$ said that they were really know the Djarum 76 advertisement "Jin Version" that aired on Television, followed by respondents who claim to know as much as $40.0 \%$ respondent, $30.0 \%$ respondents said mediocre and only $6.7 \%$ respondents who claimed not to know. From the results of these questions can be concluded that almost of respondents knew Djarum 76 advertisements "Jin Version" that aired on television. 
b. Question 2. The respondent's perception of the Djarum 76 advertisements "Jin Version" that aired on television.

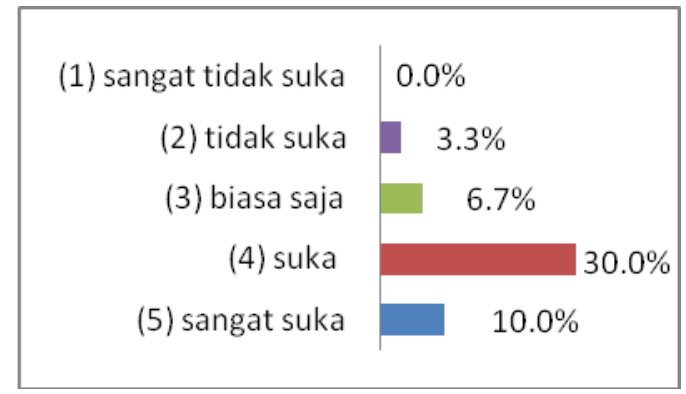

From the chart 2, can be seen from 30 rspondents which was taken as samples, there was $10.0 \%$ said that they were really like the Djarum 76 advertisement "Jin Version" that aired on Television, followed by respondents who claim they like as much as $30.0 \%$ respondent, $6.7 \%$ respondents said mediocre and only $3.3 \%$ respondents who claimed that the do not like the advertisement. From the results of this questions can be concluded that almost of respondents like Djarum 76 advertisements "Jin Version" that aired on television.

c. Question 3. The respondent's perception about how interesting the Djarum 76 advertisements "Jin Version" that aired on television.

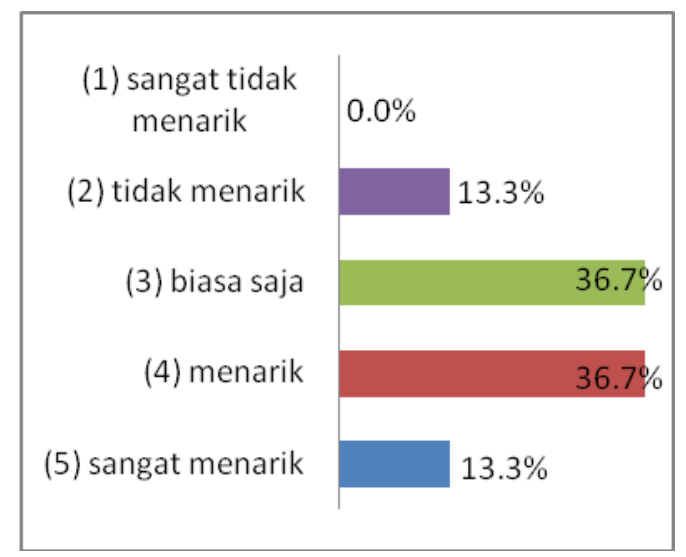

From the chart 3 , can be seen from 30 rspondents which was taken as samples, there was $13.3 \%$ said that the Djarum 76 advertisement "Jin Version" that aired on Television was very interesting, followed by respondents who said that Djarum 76 advertisement "Jin Version" that aired on Television was interesting as much as $36.7 \%$ respondent, $36.7 \%$ respondents said mediocre and only $13.3 \%$ respondents who said that the advertisement is not interesting. From the results of these questions, can be concluded that almost of respondents, said that Djarum 76 advertisements "Jin Version" that aired on television was inetreting.

d. Question 4. How often the respondent watched the Djarum 76 advertisements "Jin Version".

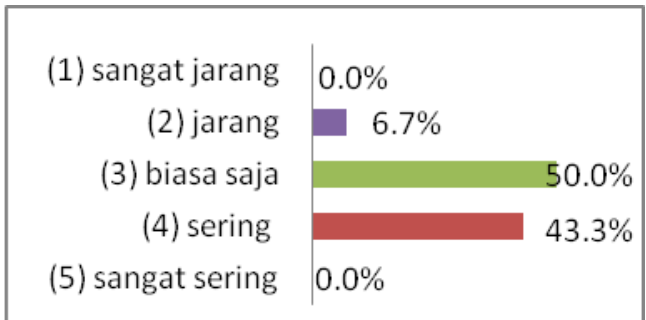


From the chart 4, can be seen from 30 rspondent which was taken as samples, there was nobody who said that they really intent to watch the Djarum 76 advertisement "Jin Version" that aired on Television, followed by respondents who said that they just often to watch Djarum 76 advertisement "Jin Version" that aired on Television as much as $43.3 \%$ respondent, $50.0 \%$ respondents said mediocre and only $6.7 \%$ respondents who said that they rarely watched the advertisement From the results of these questions, can be concluded that almost of respondents, watched Djarum 76 advertisements "Jin Version" that aired on television was inetreting.

e. Question 5. The respondent's perception about the genie figure as the central figure in Djarum 76 advertisements "Jin Version" whether he was able to attract the attention of the audience to watch the advertisements.

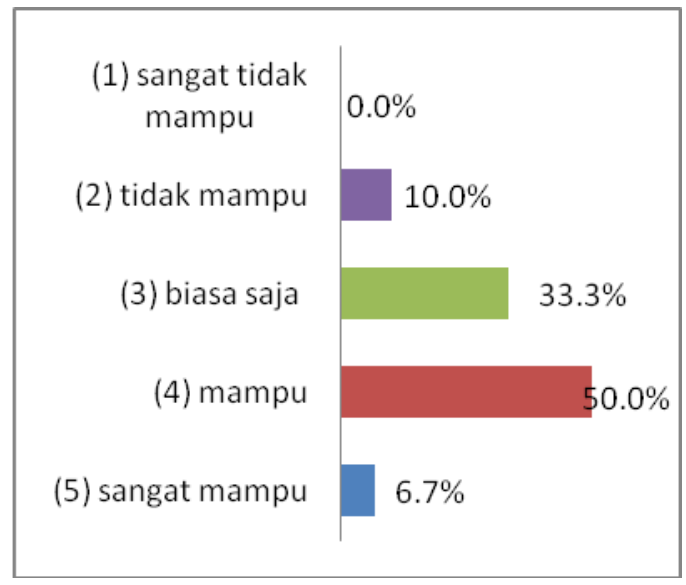

From the chart 5, can be seen from 30 rspondents which was taken as samples, there was $6.7 \%$ who said that the genie figures in Djarum 76 advertisement "Jin Version" are very capable to attract the attention of the audience to watch the advertisements, followed by respondents who said that the genie figures in Djarum 76 advertisement "Jin Version" are capable to attract the attention of the audience to watch the advertisements.as much as $50.0 \%$ respondent, $33.3 \%$ respondents said mediocre and only $10.0 \%$ respondents who said that the genie figures in Djarum 76 advertisement "Jin Version" was not capable to attract the attention of the audience to watch the advertisements. From that data can be concluded that almost of respondents, said that the appearancy of genie figures in Djarum 76 advertisements "Jin Version" was capable to attract the attention of the audience to watch the advertisements.

f. Question 6. The respondent's perception about the dialogues that appeared in Djarum 76 advertisements "Jin Version" so the audience interested to watch this advertisement again and again.

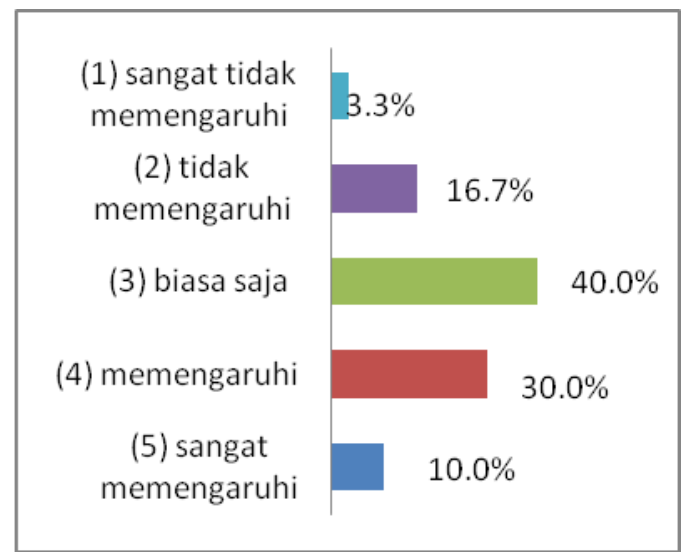


From the chart 6 , can be seen from 30 rspondent which was taken as samples, there was $10.0 \%$ who said that the dialogues in Djarum 76 advertisements "Jin Version" greatly affect the audience interested to watch this advertisement again and again, followed by respondents who said that the dialogues in Djarum 76 advertisements "Jin Version" affect the audience interested to watch this advertisement again and again, as much as $30.0 \%$ respondent, $40.0 \%$ respondents said mediocre, $16.7 \%$ respondent said that the dialogues in Djarum 76 advertisements "Jin Version" not affect the audience interested to watch this advertisement again and again, and only 3.3\% respondents who said that the dialogues in Djarum 76 advertisements "Jin Version" greatly not affect the audience interested to watch this advertisement again and again. From that data can be concluded that almost of respondents, said that the dialogues in Djarum 76 advertisements "Jin Version" greatly affect the audience interested to watch this advertisement again and again.

g. Question 7. The respondent's perception about the plot of Djarum 76 advertisements "Jin Version".

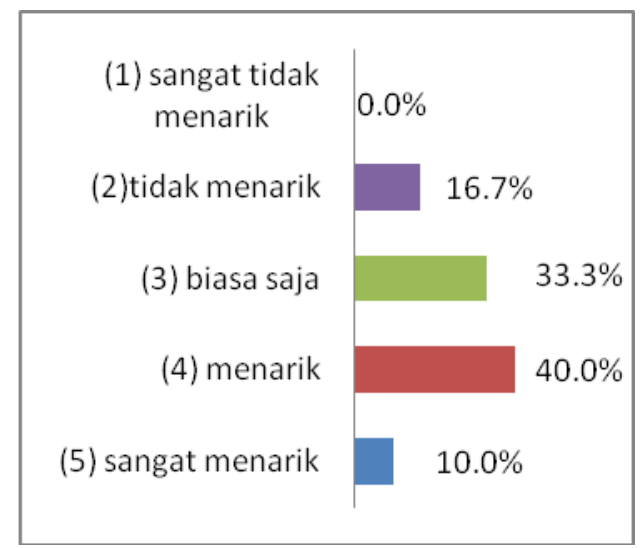

From the chart 7 , can be seen from 30 rspondent which was taken as samples, there was $10.0 \%$ who said that the plot of Djarum 76 advertisements "Jin Version" was really interesting. followed by respondents who said the plot of Djarum 76 advertisements "Jin Version" was interesting., as much as $40.0 \%$ respondent, $33.3 \%$ respondents said mediocre, and only $16.7 \%$ respondents who said the plot of Djarum 76 advertisements "Jin Version" was not interesting. From that data can be concluded that almost of respondents, said that the dialogues in Djarum 76 advertisements "Jin Version" was interesting.

h. Question 8. The respondent's perception about the plot of the Djarum 76 advertisements "Jin Version". Did the plot of Djarum 76 advertisements "Jin Version" was able to be understood by the audiences?

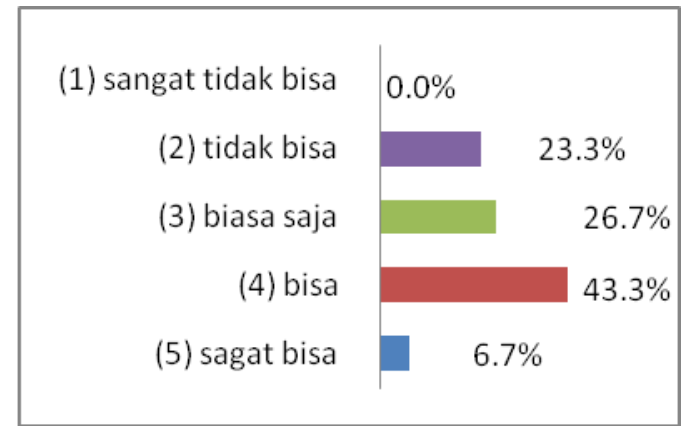

From the chart 8 , can be seen from 30 rspondents which was taken as samples, there was $6.7 \%$ who said that the plot of Djarum 76 advertisements "Jin Version" was really able to be understood by the audiences, followed by respondents who said the plot of Djarum 76 advertisements "Jin Version" was able to be understood by the audiences, as much as $43.3 \%$ respondent, $26.7 \%$ respondents said mediocre, and only $23.3 \%$ respondents who 
said the plot of Djarum 76 advertisements "Jin Version" was not able to be understood by the audiences. From that data can be concluded that almost of respondents, said that the dialogues in Djarum 76 advertisements "Jin Version" was able to be understood by the audiences.

i. Question 9. The respondent's perception about the scene that was acted by the genie figure in Djarum 76 advertisements "Jin Version".

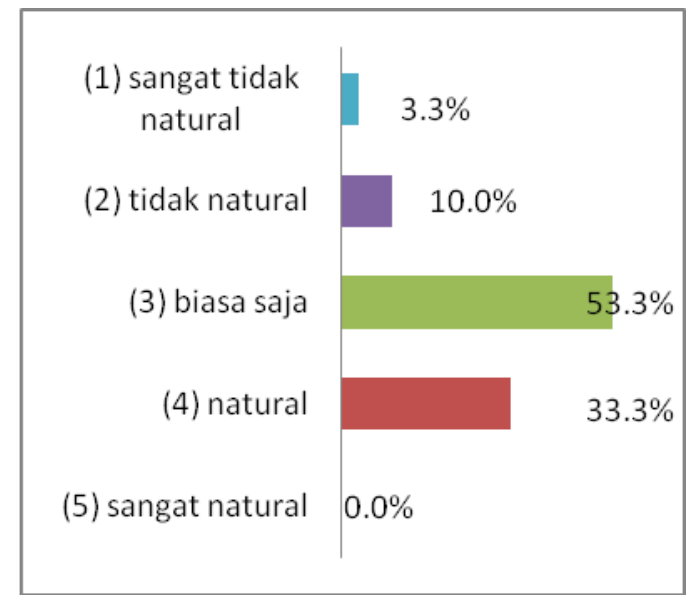

From the chart 9, can be seen from 30 rspondents which was taken as samples, there was nobody who said that the scene that was acted by the genie figure in Djarum 76 advertisements "Jin Version" greatly naturally, followed by respondents who said the scene that was acted by the genie figure in Djarum 76 advertisements "Jin Version" naturally, as much as $33.3 \%$ respondent, $53.3 \%$ respondents said mediocre, $10.0 \%$ respondent said that the scene that was acted by the genie figure in Djarum 76 advertisements "Jin Version" was not naturally and only $3.3 \%$ respondents who said the scene that was acted by the genie figure in Djarum 76 advertisements "Jin Version" really not naturally. From that data can be concluded that almost of respondents, said that the scene that was acted by the genie figure in Djarum 76 advertisements "Jin Version" naturally.

j. Question 10. The respondent's perception about did the scene act by the actors naturally?.

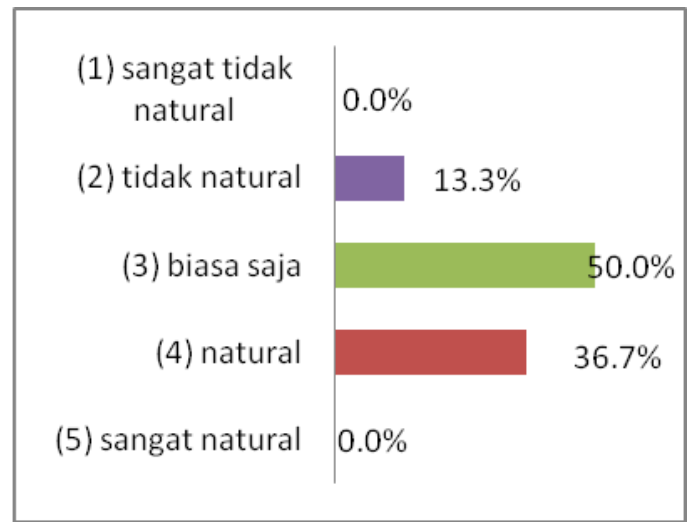

From the chart 9 , can be seen from 30 rspondent which was taken as samples, there was nobody who said that the scene that was acted by the actors in Djarum 76 advertisements "Jin Version" greatly naturally, followed by respondents who said the scene that was acted by the actors in Djarum 76 advertisements "Jin Version" naturally, as much as $36.7 \%$ respondents, $50.0 \%$ respondents said mediocre, and only $13.3 \%$ respondent said that the scene that was acted by the actors in Djarum 76 advertisements "Jin Version" was not naturally. From that data can be concluded that almost of respondents, said that the scene that was acted by the actors in Djarum 76 advertisements "Jin Version" naturally. 
k. Question 11. The respondent's perception about the slogan "yang penting hepiii..." in Djarum 76 advertisements "Jin Version".

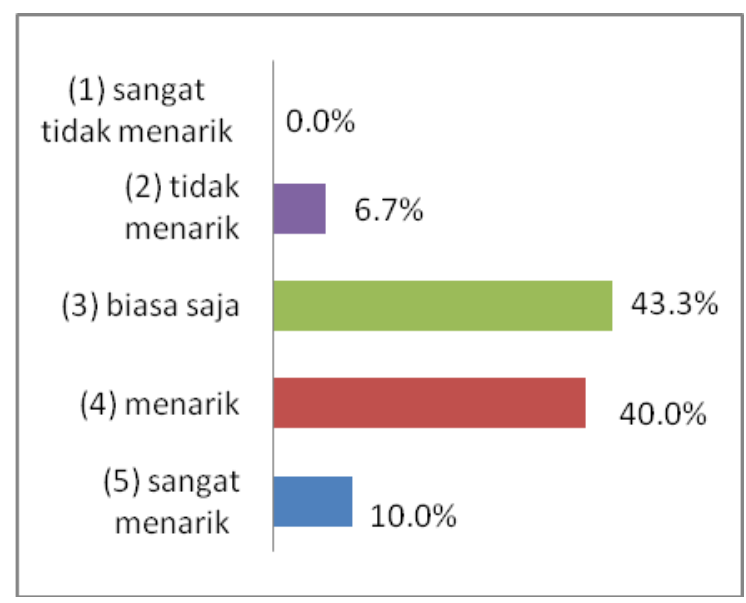

From the chart 4.11, can be seen from 30 rspondents which was taken as samples, there was $10.0 \%$ who said that the slogan "yang penting hepiii..." in Djarum 76 advertisements "Jin Version" was really interesting, followed by respondents who said the slogan "yang penting hepiii..." in Djarum 76 advertisements "Jin Version" was interesting as much as $40.0 \%$ respondent, $43.3 \%$ respondents said mediocre, and only $6.7 \%$ respondents who said the slogan "yang penting hepiii..." in Djarum 76 advertisements "Jin Version" was not interesting. From that data can be concluded that almost of respondents, said that the slogan "yang penting hepiii..." in Djarum 76 advertisements "Jin Version" was interesting.

I. Question 12. The respondent's perception about the commercial time of Djarum 76 advertisements "Jin Version".

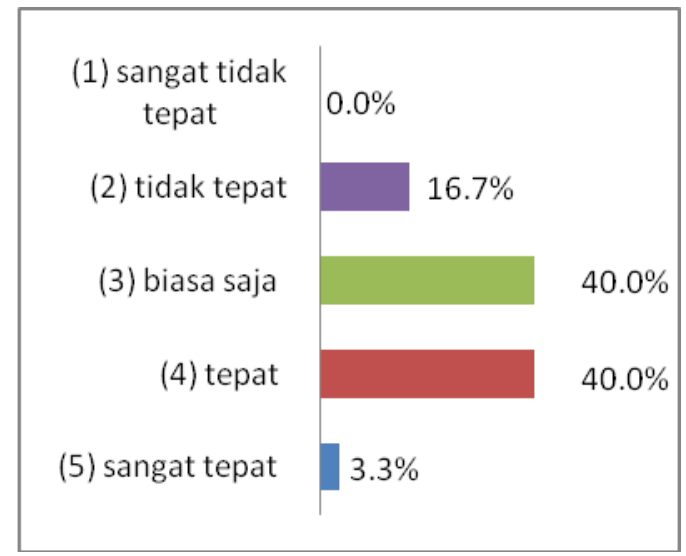

From the chart 4.12 , can be seen from 30 rspondent which was taken as samples, there was $3.3 \%$ who said that the commercial time of Djarum 76 advertisements "Jin Version"was very precisely, followed by respondents who the commercial time of Djarum 76 advertisements "Jin Version" wa precisely as much as $40.0 \%$ respondent, $40.0 \%$ respondents said mediocre, and only $16.7 \%$ respondents who said the commercial time of Djarum 76 advertisements "Jin Version" was not precisely. From that data can be concluded that almost of respondents, said that the commercial time of Djarum 76 advertisements "Jin Version" was precisely.

m. Question 13. The respondent's perception about did the visual appearance of advertisement in TV had been able to convey the message or purpose of Djarum 76 cigarette advertising? 


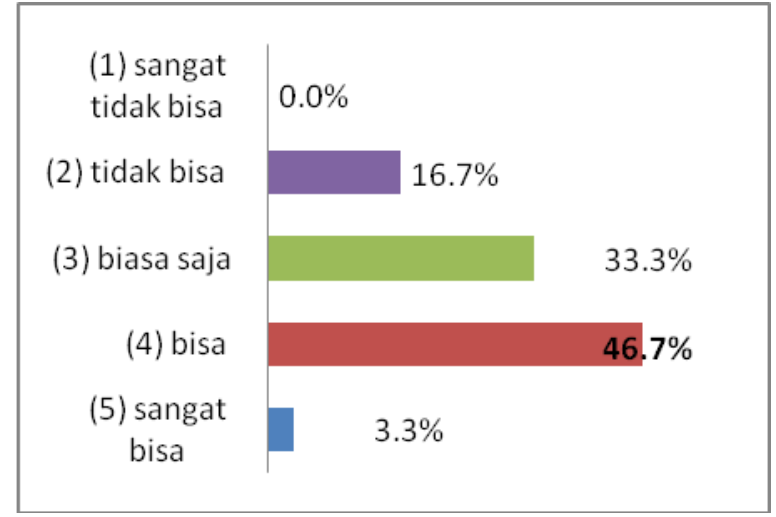

From the chart 4.13, can be seen from 30 rspondents which was taken as samples, there was $3.3 \%$ who said that the visual appearance of Djarum 76 advertisements "Jin Version in TV was really able to convey the message or purpose of Djarum 76 cigarette advertising, followed by respondents who said the the visual appearance of Djarum 76 advertisements "Jin Version in TV was able to convey the message or purpose of Djarum 76 cigarette advertising, as much as $46.7 \%$ respondents, $33.3 \%$ respondents said mediocre, and only $16.7 \%$ respondents who said the visual appearance of Djarum 76 advertisements "Jin Version in TV was not able to convey the message or purpose of Djarum 76 cigarette advertising,. From that data can be concluded that almost of respondents, said that the visual appearance of Djarum 76 advertisements "Jin Version in TV was able to convey the message or purpose of Djarum 76 cigarette advertising.

n. Question 14. The respondent's perception about did the audience understand with the purpose that was delivered by Djarum 76 advertisement "Jin Version" ?

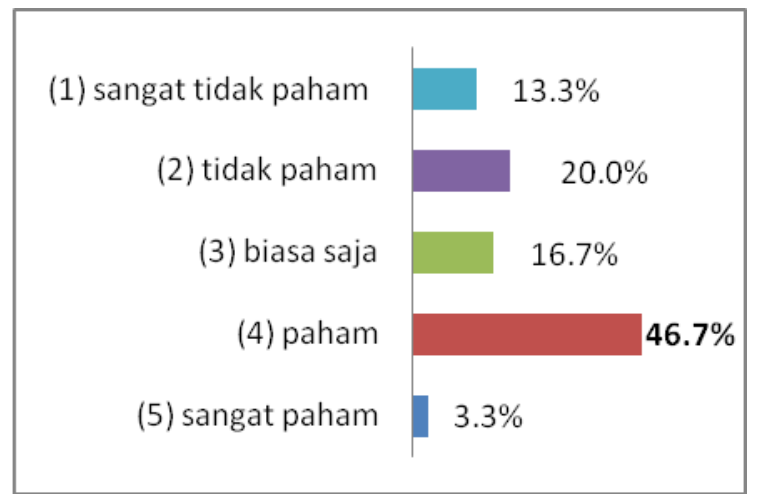

From the chart 4.14, can be seen from 30 rspondents which was taken as samples, there was $3.3 \%$ who said that the audience really understand with the purpose that was delivered by Djarum 76 advertisement "Jin Version", followed by respondents who said the audience just understand with the purpose that was delivered by Djarum 76 advertisement "Jin Version", as much as $46.7 \%$ respondent, $16.7 \%$ respondents said mediocre, $20.0 \%$ respondents who said the audience do not understand with the purpose that was delivered by Djarum 76 advertisement "Jin Version" and only $13.3 \%$ respondents who said the audience really do not understand with the purpose that was delivered by Djarum 76 advertisement "Jin Version". From that data can be concluded that almost of respondents, said that the audience understands with the purpose that was delivered by Djarum 76 advertisement "Jin Version".

o. Question 15. The general perception of respondents about Djarum 76 advertisements "Jin Version" that ware aired on television. 


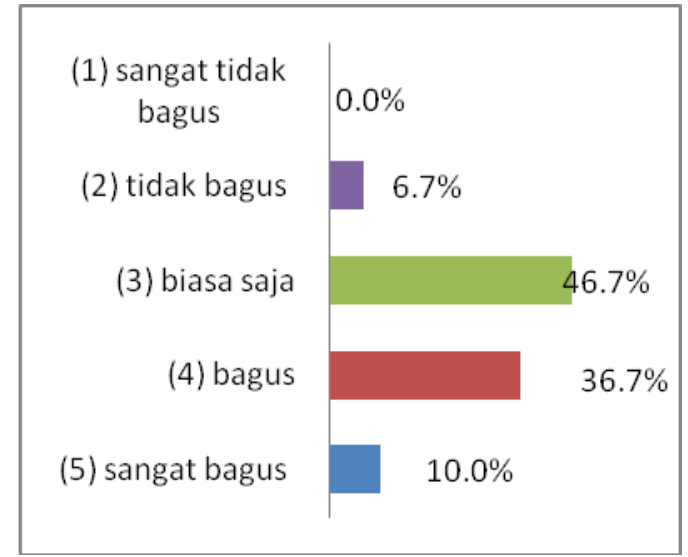

From the chart 4.15, can be seen from 30 rspondent which was taken as samples, there was $10.0 \%$ who said that the Djarum 76 advertisements "Jin Version" which was aired on television was very good, followed by respondents who said the Djarum 76 advertisements "Jin Version" which was aired on television just good, as much as $36.7 \%$ respondent, $46.7 \%$ respondents said mediocre, and only $6.7 \%$ respondents who said the Djarum 76 advertisements "Jin Version" which was aired on television was not good. From that data can be concluded that almost of respondents, said that the Djarum 76 advertisements "Jin Version" which was aired on television was good.

\section{Simpulan dan Saran}

Based on the descriptive analysis which was done deeply based on Gricean theory of maxims, can be concluded that from four kinds of maxims which is proposed by Grice (1975), there was all of them were violated in the Djarum 76 advertisements "Jin Version" that aired on television, there are: $50 \%$ advertisements violated the maxim of quantity, $10 \%$ advertisements violated the maxim of quality, $30 \%$ advertisements violated the maxim of relevance, and $40 \%$ advertisements violated the maxim manner. From that data analysis, the researcher found that most of the Djarum 76 advertisements "Jin Version violated the Gricean maxims. Besides that, based on the result analysis of audience perception, showed that many respondents who love and feel attracted to the Djarum 76 advertisements "Jin Version". Beside that based on the analysis perception, those data analysis also found that the audiences perception which is showed that they understand enough with the messages of Djarum 76 "Jin Version" although there are Gricean maxims violation. And at the end of the inquiry where the respondent was given a general questions about the impact that they got from the show of Djarum 76 advertisements "Jin Version". They gave Good impression to the advertisements, the advertisment was marked that it able to attract the attention of the audience. Based on the conclusions above, it can be prompted suggestions that the writer hope will help, there are: 1) In create the Djarum 76 advertisements; it will be much better if the advertiser observing the cooperative principle in communication, so that audiences easily capture the meaning of the message conveyed by the advertisements. 2) PT Djarum is expected to take many other relevant marketing strategies to reinforce the image that has been cultivated through Djarum 76 advertisement "Jin Version" that was aired on television. 3) Further research was expected to be able to expand the population and sample research on other segments of society, with the purpose of strengthening the results of research that has researchers do. 


\section{Daftar Pustaka}

Alwi, Hasan, dkk. 2003. Tata Bahasa Baku Bahasa Indonesia (edisi ke tiga. Jakarta:Balai Pustaka.

Arikunto, Suharsimi. 2006. Prosedur Penelitian Suatu Pendekatan Praktik. Jakarta : Rineka Cipta.

Bach, K. and Harnish, R. 1991. Linguistic Communication and Speech Acts. Cambridge, MA: MLT Press.

Bungin, Burhan, 2001. Imaji Media Massa: Konstruksi dan makna Realitas Sosial Iklan Televisi dalam Masyarakat Kapitalis. Yogyakarta: Jendela

Darmadi Durianto, dkk. (2003). Invasi Pasar dengan Iklan yang Efektif. Jakarta: Gramedia Pustaka Utama.

Douglas, S.P. \& Craig, C.S. 2006. On improving the conceptual foundations of international marketing research. Journal of International Marketing 14, pp. 1-22.

Fromkin, Victoria, Rodman, Robert \&Hyams, Nina.(2003). An Introduction To Linguistics. USA:Wadsworth

Gazdar, Gerald (1979) Pragmatics, Implicature, Presupposition and Logical Form. Florida Academis Press. INC

Grice, H.Paul (1975) Logic and Conversation. New York: Oxford University Press.

Gunarwan. 1994. Pragmatik. Jakarta: Lembaga Bahasa. Jakarta: Unika Atmajaya.

Holmes, Janet.(1992). An Introduction To Linguistics. Longman: University of California.

Jefkins, Fank, 1997. Periklanan ( Terjemahan Haris Munanda ). Jakarta: Erlangga.

Kasali, Rhenald. (1995). Manajemen Periklanan - Konsep dan Aplikasinya di Indonesia, Jakarta : Pustaka Utama Grafiti.

Kridalaksana, Harimurti. 2008. Kamus Linguistic. Jakarta: PT Gramedia Pustaka Utama.

Kotler , p. 2003. Marketing insights from A to Z.Jakarta: Erlangga

Levinson, S. C. (1995). Pragmatics. Cambridge: Cambridge University Press.

Moleong, L. J. 2010. Metodologi Penelitian Kualitatif. Bandung : PT Remaja Rosdakarya.

Lyons, John. 2002. Language and Linguistics. Cambridge: Cambridge University Press

Leech, Geoffrey. 1983. Principle of Pragmatics. United Stated of America: Longman Group.

Miles, M. B. \& Huberman, A.M. (1994).Qualitative Data Analysis Second Edition. USA: Sage Publication Inc.

Nanda, Sheila. 2012. Conversational Implicature of the Presenter Take Me Indonesia. http://rangmalalak.wordpress.com / Retrieved January 2014,

Rachmadi F, 1993, Public Relation dalam Teori dan Praktek, Jakarta, PT. Gramedia Pustaka Utama.

Robbins, P. S. \& Timothy, A. 2008. Organizational behavior. Jakarta: Salemba Empat

Subroto.1992. Teknik Pengumpulan Data. Jakarta : PT Gramedia.

Suhartono, M.T. 2013. Analisis Pemaknaan Iklan Djarum 76 versi Wakil Rakyat. Ejournal.ikom.fisip_unmul.ac.id 
Sutopo H.B. 2002. Metodologi Penelitian Kualitatif Dasar Teori dan Terapannya Dalam Penelitian. Surakarta : Universitas Sebelas Maret.

Sudiana, Dendi. 1986. Komunikasi Periklanan Cetak. Bandung: Remaja Karya.

Thoha, Miftah. 2000. Perilaku Organisasi; Konsep Dasar dan Aplikasinya. Jakarta: PT. Raja Grafindo.

Wulandari. 2007. Implicature Analysis on the Funniest Joke in the World article in the Reader "Digest". http:// / retrieved on January 2014

Vogt, Crystal. 2005. Perception in advertising. http://smallbusiness.chron.com/perceptionadvertising-25438.html/retrived on 29 April 2014.

,2004. Djarum PT History. http://www.fundinguniverse.com/company-histories/djarum-pthistory/retrived on 5 April 2013.

,2014. PT Djarum website. http://www.djarum.com/index.php/en/retrived on 4 April 2014. 